\title{
KORT OVERZICHT VAN DE EXPLOITATIE VAN DEN RIJKSTELEGRAAF IN 1886.
}

Aan het Verslag aan den Koning over de telegraten in 1886 ontleenen wij het volgende:

Het Rijkstelegraafnet bestond op 1 Januari 1887 uit 4.770 kilometer telegraaflijn en 17.019 kilometer telegraafdraad, alzoo uit 69 kilometer lijn en 239 kilometerdraad meer dan op 1 Januari 1886. Deze vermeerdertng was het gevolg der opneming van nieuwe kantoren in het telegraafnet, alsmede van uitbreiding der verkeersmiddelen met Duitschland. Van de 4.770 kilometer lijn liepen 2.614 langs spoorwegen en 2.156 langs andere wegen of kanalen. De lengte op I Januari 1887 der aanwezige lijnen onder den grond bedroeg ongeveer in ijzeren buizen 18 , in asphaltbuizen 12 , in aardenbuizen 1 en in kabels 92 kilometer, en die der lijnen onder water in kabels 169 kilometers.

In 1885 en 1886 zijn een aantal lijnen aangelegd in overleg met het Departement van Marine tot invoering van een kustbewaking of kustwacht, ten einde schepen, die in nood verkeeren, spoedig hulp te kunnen verleenen.

Een elektrische verbinding is tot stand gebragt van kustposten onderling, van deze met de stations van reddingmaatschappijen en verblijfplaatsen van ambtenaren van het loodswezen, alsmede met plaatsen, waar redding- of sleepbooten of ook andere middelen tot het verleenen van hulp aan in gevaar verkeerende schepen beschikbaar zijn. Voor den aanleg der noodige geleidingen heeft het Departement van Waterstaat, Handel en Nijverheid een uitgaaf van $f 53,000$ gedaal. De berigtenwisseling heeft plaats per telephoon. Op sommige punten zijn wekkers geplaatst, om personen te kunnen oproepen. Hoewel zulks welligt goedkoop is, zoo vreezen wij, dat de inrigting bij noodweer, vooral 's nachts, zal falen, en ware het welligt beter geweest eene lijn langs de geheelc kust aan te leggen, onafhankelijk van de rijkstelegraaflijn en allerlei kunstige verbindiugen. 
In 1886 zijn 21 Rijkstelegraafkantoren geopend; van deze kantoren zijn 20 voor telephoondienst ingericht. Het telegraafkantoor in den lichttoren te Wester-Schouwen is gesloten en het zelfstandig telegraafkantoor te Delfshaven veranderd in een hulpkantoor van Rotterdam. Door bijzondere ondernemingen zijn 6 kantoren voor het algemeen telegrafisch verkeer opengesteld, als:

3 door de Hollandsche IJzeren Spoorweg maatschappij, 1 door de Nederlandsche Centraalspoorweg-maatschappij en 2 door concessionarissen van bijzondere telegraafondernemingen; daarentegen werden 2 bijzondere kantoren gesloten.

Op 31 December 1886 bedroeg het aantal telegraafkantoren in Nederland 618; van deze waren 231 gewone rijkstelegraaf kantoren, 91 rijkstelegraaf kantoren met telephoondienst, en 296 kantoren van hijzondere ondernemingen.

Van de rijkstelegraafkantoren waren 171 met vereenigde posten telegraafdiensten, uamelijk 144 post- en telegraafkantoren en 27 telegraaf- en hulpkantoren.

Van de 322 rijkskantoren hadden op 31 December 1886:

3 dag- en nachtdienst;

6 verlengden dag- on vollen Zondagdienst;

9 verlengden dag- en beperkten Zondagdienst;

1 doorloopenden dag- en Zondagdienst;

64 doorloopenden dag- en beperkten Zondagdienst;

239 beperkten dienst.

Op de verbindingen van het beurskantoor te Amstcrdam mot dat te Rotterdam, alsmede met de onderstaande buitenlandsche beurzen zijn het volgend aantal berigten gewisseld:

1885.

1886.

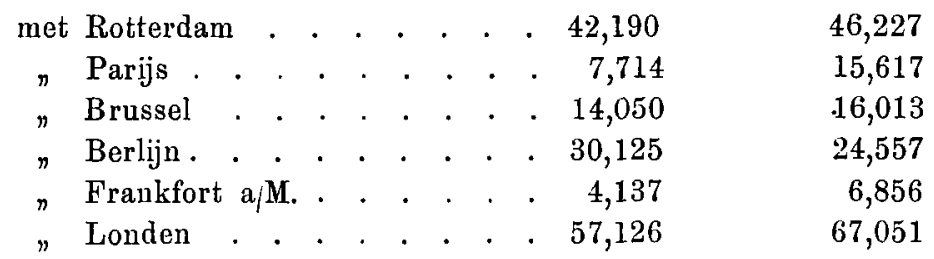

Op de rechtstreeksche verbinding tuschen Londen en Berlijn, met overdraging te Amsterdam, werden 85,678 telegrammen in 1886 overgebragt tegen 55,864 stuks in 1685 .

Het aantal stadtelegrammen, in 1886 tusschen de hoofd- on hulpkantoreu te Amsterdam en Rotterdam gewisseld, bedroeg te Amsterdam 5980 stuks tegen 4874 in 1885 ; te Rotterdam 324 stuks tegen 178 in 1885. 
Door middel van de aansluitingslijn der Nederlandsche BellTelephoon-Maatschappij werden te Amsterdam aangeboden 11,606 en afgeleverd 12,813 telegrammen, tegen respectivelijk 8,455 en 10,352 in 1885 . Te Rotterdam bedroegen in 1886 deze cijfers 3,208 en 3,942 tegen 3,991 en 5,491 in 1885 ; op de overige aansluitingen werden gewisseld te Arnhem 1,455, Dordrecht 2,044, Enschede 58, 's Gravenhage 1,185, Groningen 1,002, Haarlem 2,821, Utrecht 4,358 en Zaandam 65 telegrammen.

Van de bevoegdheid, om in de telegrammen aflevering aan den geadresseerde per telephoon te bevelen, werd in 1886 voor 286 telegrammen gebruik gemaakt tegen 406 in 1885 .

De Nederlandsche Gist- en Spiritusfabriek te Delft wisselde met het rijks-telegraaf kantoor aldaar 5,083 telegrammen; de firma Nicola-Koechlin en Co to Voorburg met het rijkstelegraaf kantoor te 's Gravenhage 5,674, en de beetwortelsuikerfabriek Sint-Antoine met het rijkstelegraaf kantoor te Oudenbosch 1,167 stuks.

Een aantal concessien is in 1886 verleend tot den aanleg on het gebruik van telegraaflijnen ter bediening met telephonen; even als vroeger is aan enkelen dezer concessien tot voorwaarde gesteld de jaarlijksche betaling van een vergunningsrecht, zooals de Minister zegt, ter goedmaking van de geldelijke schade voor de schatkist, welke in vele gevallen het gevolg is of kan zijn van den aanleg en het gebruik van die particuliere electrische geleidingen, welke twee plaatsen in verschillende gemeenten gelegen verbinden, en dus vele brieven en telegrammen aan het Rijksposten telegraafverkeer onttrekken. Te vergeefs is aan de Regeering gevraagd op te geven op welken wettelijken grondslag dat vergunningsrecht rust; het antwoord blijft achterwege, onzes inziens omdat de Regeering geen wettelijken grondslag kent. Dat het heffen van dit vergunningsrecht zeer wordt uitgestrekt blijkt, doordien voor het vergunningsrecht tusschen den watertoren te Leeuwarden en de pompwerken te Grouw jaarlijks moet worden betaald $f 100$.

$\mathrm{Bij}$ het in 1886 gehouden onderzoek naar de bekwaamheden van postambtenaren in den telegraafdienst en van telegraafambtewaren in den postdienst is van de 89 postambtenaren en van de 27 telegraafambtenaren, die zich aan het examen hebben onderworpen, aan 43 on 13 het verlangde radicaal voor den telegraafen den postdienst uitgereikt.

Het personeel van den Rijkstelegraaf bestond op 1 Januari 1887 uit: 
1 hoofddirecteur, chef der afdeeling;

1 inspecteur, chef der onderafdecling rekenplichtig beheer;

1 hoofdeommies;

3 commiezen;

2 adjunct-commiezen;

1 inspecteur, chef der onderafdeeling technisch beheer;

3 adjunct-commiezen;

2 directeuren;

1 onder-direeteur;

4 telegrafisten;

1 opzichter;

8 klerken;

3 kantoorknechts;

9 lijninspecteurs;

Bij het Departement werkzaam.

Bij het Hoofdbestuur weekzaam.

218 directeuren van kantoren, waaronder 68 postambtenaren, tevens met het beheer van een rijkstelegraaf kuntoor belast;

56 onder-directeuren;

513 telegrafisten, waaronder 17 vrouwelijke;

160 klerken, waaronder 19 vrouwelijke;

9 adsistenten, waaronder 5 vrouwelijke;

8 leerlingen-telegrafist, waaronder 1 vrouwelijke;

1 tijdelijke klerk;

16 opzichters;

21 lijnwachters;

1 tijdelijke lijnwachter;

23 werklieden en bedienden aan de herstellingwerkplaats,

4 werklieden te Amsterdam;

1 werkman te Rotterdam;

738 bestellers aan de kantoren, waaronder 478 brieven- en telegrambestellers;

1 concierge te Rotterdam.

Het grootste personeel is op de volgende kantoren:

Amsterdam met 279 telegraaf beambten en 90 bestellers

Rotterdam

's Gravenhage " 41

Arnhem $\quad$ 28

Utrecht $\quad " 21$

Groningen $\quad$ 19

Leeuwarden $" 16$

$\begin{array}{lrr}n & 34 & n \\ n & 18 & n \\ n & 10 & n \\ n & 10 & n \\ n & 6 & n\end{array}$


Het geheel aantal betaalde berichten bedroeg in 1886 een aantal van $3,622,810$ stuks tegen $3,444,698$ in 1886 , alzoo een vermeerdering van 178,112 .

Het aantal binnenlandsche berigten beliep 2,030,201 in 1886, tegen $2,001,743$ in 1885 , alzoo 28,458 meer.

Het aantal buitenlandsehe berigten was $1,239,553$ in 1886 tegen $1,159,763$ in 1885 , alzoo 79,790 meer. Van deze berigten waren in 1886 in ronde cijfers met en door Belgie 418,000, Duitschland 492.000 en Engeland 330,000 tegen respectievelijk 395,000, 467,000 en 298,000 in 1885 .

Het aantal doorgezonden berigten bedroeg 353,056 in 1886 tegen 283,192 in 1885 ; deze vermeerdering' is veroorzaakt door het grooter aantal berigten tusschen Duitschland en Engeland De kantoren waar de meeste telegrammen werden ontvangen, verzonden en overgenomen waren:

\begin{tabular}{|c|c|c|c|c|c|c|c|c|c|c|}
\hline Amslerdan & met & $2,746,704$ & leg & en & en & $\mathrm{u} 1$ & ore & val & & 646,000 \\
\hline Rotterdam & $\eta$ & $1,224,518$ & $"$ & $n$ & $n$ & " & $n$ & $n$ & ) & 307,000 \\
\hline 's Gravenhage & ” & 323,181 & $n$ & $B$ & » & 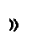 & 》 & y & " & 107,000 \\
\hline Ainhem & $"$ & 211,466 & » & $1)$ & $"$ & ) & $"$ & $"$ & )) & 23,000 \\
\hline Groningen & " & 188,905 & $"$ & $n$ & " & $"$ & $\eta$ & $\nu$ & ") & 27,000 \\
\hline Utrecht & ” & 164,706 & $\eta$ & 》 & $"$ & $"$ & " & $"$ & ) & 41,000 \\
\hline Leeuwarden & $»$ & 112,214 & $n$ & $"$ & $n$ & $"$ & $"$ & $"$ & " & 14,000 \\
\hline Zwolle & ” & 86,529 & : & 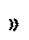 & " & $"$ & $y$ & $"$ & $n$ & 12.000 \\
\hline Dordrecht & $"$ & 83,355 & " & $n$ & $n$ & $"$ & $"$ & $"$ & " & 16,000 \\
\hline 's Hertogenbosch & " & 79,503 & $n$ & $n$ & $"$ & " & $"$ & $»$ & 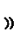 & 10,000 \\
\hline
\end{tabular}

Op 100 gewisselde telegrammen werden gevouden:

1885.1886.

Binnenlandsche telegrammen . . . . . . . $58 \quad 56$

Telegrammen door Nederlandsche kantoren met

het buitenland gewisseld. . . . . . . 34

Doorgezonden telegrammen. . . . . . . . 510

Bij vergelijking van het verkeer van 1886 met dat van 1885 blijkt van de volgende toeneming ten honderd:

Binnenlandsch verkeer . . . . . . . . . . . . 1

Verkeer van Nederland met en over Belgie . . . . . 6

$n n \pi n \pi$ Duitschland . . . 5

$n \pi n " n$ Groot-Brittannie . 11

$\pi \quad$ via Nederland tusschen Groot-Brittannie en

Duitschland . . . . . . . . . . . . . . 24

Het geheele verkeer te zamen genomen . . . . . . 5

Hieronder laten wij volgen het aantal telegrammen van 2 tot 5 , 6 tot 10 woorden, enz. voorkomende op iedere 1000 telegrammen. 
Met het oog op het in werking komen der nieuwe tarieven voor het internationaal verkeer op 1 Juli en voor het binnenlandsch verkeer op 7 Juli 1886 geschiedt de aanwijzing voor het eerste en tweede half jaar ieder af zonderlijk.

\begin{tabular}{|c|c|c|c|c|}
\hline Váll & 2 & tot & 5 & woorden \\
\hline 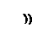 & 6 & 》 & 10 & 》 \\
\hline D) & 11 & $\eta$ & 15 & ) \\
\hline ) & 16 & ) & 20 & $\eta$ \\
\hline n) & 21 & ) & 30 & $n$ \\
\hline ) & 31 & ) & 40 & " \\
\hline 1 & 41 & 》 & 50 & ) \\
\hline & bov & & 50 & $\theta$ \\
\hline
\end{tabular}

Nederland. Duitschland. Gr.-Brittannie. Belgie.

1e $2 \mathrm{e}$ half j. ie $2 \mathrm{ehalfj.} \mathrm{te} 2 \mathrm{ehalfj}$. 1e $2 \mathrm{ehallj}$.

\begin{tabular}{|c|c|c|c|c|c|c|c|}
\hline 33 & 201 & 190 & 161 & 314 & 303 & 50 & 75 \\
\hline 331 & THO & 441 & 456 & 404 & 424 & 385 & 397 \\
\hline 318 & 305 & 214 & 228 & 170 & 159 & 311 & 284 \\
\hline 160 & 155 & 78 & 93 & 63 & 64 & 135 & \\
\hline 106 & 95 & 56 & 47 & 36 & 37 & 76 & \\
\hline 26 & 24 & 13 & 10 & 8 & 9 & 20 & \\
\hline 9 & 8 & 4 & 3 & 2 & 2 & 6 & \\
\hline 17 & 12 & 4 & 2 & 3 & 2 & 8 & \\
\hline
\end{tabular}

Het gemiddeld woordental was in 1886 in het binnenlandsch verkeer 15, in dat met Belgie 13, Duitschland 10 en Groot. Brittannie 9.

Van honderd bij rijkstelegraafkantoren aangeboden binnenlandsche telegrammen handelden over:

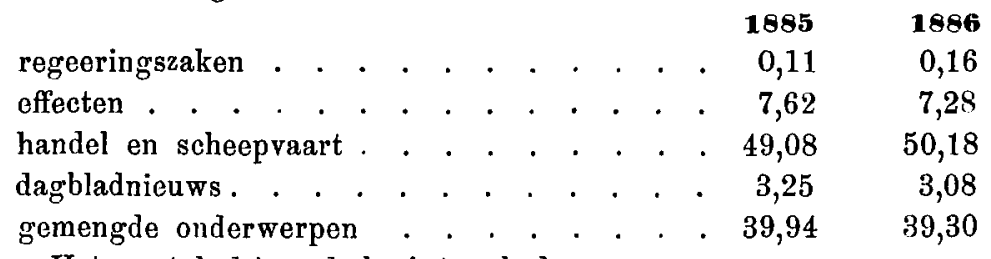

Het aantal dringende berigten bedroeg:

$1885 \quad 1886$

in het binnenlandsch verkeer . . . . . . 19,018 20,638 in het buitenlandsch vorkeer . . . . . . $32,670 \quad 36,527$

Telegrafische postnoissels werden verzorden:

\section{5}

Binnen Nederland . . . . . . 10,565 stuks 10,340 stuks Tusschen Nederl, en vreemde Staten 703 n 1,454 " Bedrag binnenlandsch verkeer . $f$ 599,158 $f \mathbf{5 1 2 , 9 6 2}$ Bedrag buitenlandsch verkeer . $f$ 63,179 $f$ 98,381

Dooreengenomen was de opbrengst van een telegram, gewisseld :

Tusschen twee binnenlandsche kantoren . . f $0.29 \quad f 0.31$ Met en over Belgie. . . . . . . . . . „0.35 0.35

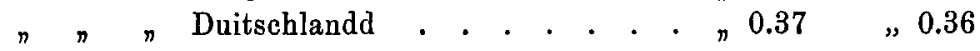
$n \pi$ Groot-Brittannie en Ierland . . ${ }_{n} 0.25,0.24$ Tusschen buitenlandsche kantoren via Nederland ${ }_{*} 0.20 \quad, 0.19$ Met den Nieuwjaarsdag van 1886 is voor het eerst en bij wijze 
van proefneming gelegenheid gegeven tot het doen overbrengen tusschen de Nederlandsche rijkstelegraaf kantoren van den inhoud van nieuwjaarskaarten tegen den prijs van 10 cent voor iederen naam.

Er werden 11,882 telegrammen van dien aard aangoboden. Met 1 Januari 1887 is de proef herhaald, maar het aantal telogrammen bedroeg toen slechts 6,480 . Het nieuwtje was er af.

In 1886 werden 135,552 stuks telegramzegels verkocht tegen 125,936 in 1885 . Bij de rijkstelegraaf kantoren zijn in 1886 aangenomen 43,729 telegrammen, waarvan de kosten met telegramzegels waren voldaan, tegen 39,355 in 1885 .

\section{5}

1886

De geheele opbrengst van den Rijks-

telegaaf bedroeg. . . . . . . . $f 1,057,923$

$f 1,123,397$

De totale uitgaven van den Rijkstelegraaf $, 1,711,801,1,594,141$

Kosten van personeel en materieel roor

de exploitatie, onderhoud van lijnen

en kantoren . . . . . . . . . n 1,631,411 „1,546,262

(De laatstgenoemde kosten zijn eon gedeelte der totale uitgaven, hierboven vermeld; onder de totale uitgaven zijn ook begrepen de kosten van nieuwe lijnen. Tusschen de cijfers over 188j in dit opstel voorkomende, en die vermeld in den vorigen jaargang van dit tijdschrift op bl. 1090 is verschil, omdat de uitgaven over 1885 toen nog niet volledig bekend waren. De Minister van Waterstaat, Handel en Nijverheid deelt mede in zijn Verslag, gedagteekend 24 Juni 1886 , dat de uitgaven over 1885 nog niet volledig bekend waren, maar zoo nauwkeurig mogelijk zịjn geraamd en wel de totale uitgaven op $f 1,739,544$ en de kosten van personecl, onz. op $f 1,655,215$, terwijl in het Verslag over 1886 wordt vermeld, dat die uitgaven respectievelijk hebben bedragen $f 1,711,801$ en $f 1,631,411$, vrij groote verschillen, die dus eerst na 24 Juni 1886 zijn bekend geworden).

Hoewel het bestuur der posterijen en telegrafie onder denzelfden persoon staat, zoo bewijzen de verslagen over deze beide takken van dienst op nieuw, hoe weinig zamenwerking en overeenstemming er nog bestaat. De uitgaven der posterijen zijn gesplitst in verschillende onderdeelen, terwijl zulks van de telegrafie niet het geval is; bij een vergelijking van bl. 47 van het Verslag der Posterijen met bl. 63 en 64 van dat der Telegrafen valt zulks dadelijk in het oog. Hoe gebrekkig de splitsing van de uitgaven der posterijen ook is, zij is een juweel in vergelijking met die der uitgaven voor den Rijkstelegraaf. 
De opbrengst van den Rijkstelegraaf over 1886 is in ronde sommen geraamd van het binnenlandsch verkeer op $f 620$, 100 ; van het verkeer met Belgie op $f 147,000$; met Duitsehland op $f 175,000$; met Engeland op $f 79,000$ en van de doorgezonden berigten op $f 68,000$. (Over 1885 bedroegen deze sommen $f 580,000$; $f 137,000, f 171,000 ; f 74,000$ en $f 56,000)$. Bovengenoemde opbrengst moet nog vermeerderd worden, zooals met $f 14,883$, voor hetgeen door gemeenten of particulieren is gestort tot aanvulling der opbrengst van kantoren tot het bedrag der doorloopende kosten; met $f 2,270$ als bedrag der oningewisselde antwoordbewijzen; met $f 6,272$ voor het recht van gebruik van adressen in verkorten of overeengekomen vorm; met $f 1,291$ als bedrag der ontvangen gelden wegens vergoeding voor toestelbediening op particuliere geleidingen; met $f$ 1,972 als bedrag der ontvangen gelden wegens den telegraafdienst langs het Noordzeekanaal, enz.

Vergelijkt men voor 1885 en 1886 alleen de opbrengst en do exploitatickosten (de kosten van aanleg van nieuwe lijnen daar buiten gelaten) dan blijkt, dat in ronde sommen in $1886 \mathrm{de}$ opbrengst $f 65,000$ meer, en de exploitatiekosten $f 85,000$ minder hebben bedragen, dals in 1885 , zoodat 1886 met 1885 verrelijkende or een voordeelig verschil is van $f 150,000$. Terwijl in 1885 , alleen de opbrengst en de exploitatiekosten in aanmerking nemende, or een te kort was van $f 573,000$, beliep dit in 1886 slechts $\int 423,000$.

Wij verheugen ons zeer in dezen goeden uitslag, maar deelen niet het gevoelen van den Minister van Waterstaat, Handel en Nijverheid, die op bl. 41 van het Verslag, de hoogere opbrengst voor een deel toeschrijft aan de verhooging van het binnenlandscho telegramtarief, maar vooral aan de toeneming van het buitenlandscht verkeer en van de doorzending. Vergelijkt men de opbrengst van 1886 met 1885 dan blijkt, dat in 1886 meer heeft opgebragt het Binnenlandsch verkeer $f 40,000$; het verkeer met Belgie $f 10,000$; met Duitschland $f 4,000$; met Engeland $f 5,000$ en de doorgezonden berigten met $f 12,000$. De meerdere opbrengst is dus hoofdzakelijk aan het binnenlandsch verkeer en niet vooral aan het buitenlandsch verkeer en de doorzending te danken.

De Minister zegt voorts in zijn Verslag: „naast de hoogere opbrengst in 1886 is eene vermindering van uitgaven van $f 117,660$ verkregen ten gevolge waarvan de kosten per telegram, die in 1885 $f 0,473$ bedroegen, in 1886 tot $f 0,427$ zijn yedaald, oen cijfer 
lager dan ooit te voren, het jaar 1868 alleen uitgezonderd.

Die mindere uitgaaf is een gevolg van de inkrimping van het grotal ambtenaren, de vereeniging van post- en telegraafdiensten, die in de laatste jaren ook tot meer belangrijke kantoren is uitgestrekt en een meer billijke verdeeling der kosten van den vereenigden dienst."

Laat ons den Minister op den voet volgen in zijn betoog; in de eerste plaats zegt de Minister, dat een vermindering van nitgaven is verkregen van $f 117,660$ : hier merken wij op, dat onder deze uitgaven ook zijn begrepen de kosten van aanleg van nieuwe lijnen en dergelijke uitgaven.

Het gaat niet aan, om als men minder nieuwe lijnen aanlegt, kantoren bouwt, enz. te zeggen, dat zijn mindere uitgaven; die aanleg moge men uitstellen, maar uitstel geoft hier geen afstel. Wil men bewijzen dat minder is uitgegeven dan moeten de cijfers vergeleken worden, die de exploitatie in 1886 en 1885 heeft gekost, en dan vinden wij dat de exploitatie in 1886 ongeveer $f 85,000$ minder heeft gekost dan in 1885 . Verheugt $u$ niet te spoedig, lezer; want de Minister wijst zelf aan het slot van zijn eigene verheerlijking de reden dier mindere uitgaaf aan, namelijk do meer billijke verdeeling tusschen de administratie van de posterijen en van den Rijkstelegraaf der kosten voor een kantoor, waar de beide diensten vereenigd zijn. Die kosten werden tot 1886 voor cen groot gedeelte gebracht ten laste van den Rijkstelegraaf, maar thans komen $\frac{62}{100}$ ten laste van den postdienst en $\frac{38}{100}$ van den Rijkstelegraafdienst. Hoeveel deze verandering van boeking bedraagt, lsunnen wij niet juist opgeven, omdat zooals wij hiervoren reeds aangaven, de splitsing der uitgaven zeer gebrekkig is. In het Verslag der Posterijen over 1885 vindt men onder de uitgaven voor Aandeel in de traktementen der telegraafambtenaren $f 31,000$. In het Verslag der Posterijen over 1886 is deze uitgave verdwenen, maar wordt op het eind van genoemd Verslag vermeld, dat de uitgaven van de vereenigde post- en telegraafdienst in 1886 hebben bedragen $f 730,608$, waarvan $\frac{62}{100}$ dus $f 452,977$ ten laste vall den postdienst komt, en onder de uitgaven is begrepen, terwijl het overige $\frac{38}{100}$ onder de uitgaven van den telegraafdienst is begrepen. Wij kunnen niet beslissen, of deze meerdere gelden van $f 452,217-31,000=f 421,977$ vroeger geheel door den Rijkstelegraaf werden betaald; zoo ja, dan zijn de uitgaven over 1886 aanmerkelijk hooger, dan voor 1885. Voor de Schatkist doet het er niet toe, of de gelden door de posterijen of de rijkstele- 
grafen worden betaald; dat is een kwestie van boeking. Bezuiniging schijnt er op de telegrafie niet te zijn, alleen gebracht ten laste der posterijen, wat vroeger door de telegrafie werd betaald.

De Minister schrijft de mindere uitgaaf voorts toe aan de inkrimping van het getal ambtenaren; bij een vergelijking van het getal ambtenaren op 1 Januari 1887 met dat op 1 Januari 1886, zooals de Minister het aangeeft op blz. 36 van zijn Verslag, blijkt dat op 1 Januari 1887 meer in dienst waren dan op 1 Januari 18862 directeuren en 8 telegrafisten en minder in dienst 1 onderdirecteur, 13 klerken en 23 leerlingen-telegrafist. Wat het getnl ambtenaren betreft, hierop is verminderd, maar de som aan traktementen uitbetaald zal bijna gelijk staan, zoodat finantieel het verschil niet bijster groot zal zijn. Hier komt bij, dat doordien geen leerlingen-telegrafist zijn aangesteld, maar de ontbrekende telegraafbeambten gerecruteerd worden uit het mindere personeel van geagreëerden en adsistenten, het gehalte der telegraafbeambten vermindert. Deze komen, zonder examen gedaan te hebben, in dienst, worden daarna met een verlicht examen bij den telegraafdienst toegelaten, en geven daardoor veel wat minder waarborg van ontwikkeling dan de leerlingen-telegrafist. De Minister wijst ook op de vereeniging van post- en telegraafkantoren; uit het Verslag blijkt, dat in 1886 slechts 8 dergelijke kantoren zijn vereenigd tegen 10 in 1885. De hoofdoorzaak der zoogenaamde mindere uitgaaf is, dat ten laste van de posterijen is gebragt, wat vroeger door telegrafie werd betaald.

Het aantal betaalde telegrammen door bijzondere maatschappijen behandeld, dus de dienst-telegrammen buiten rekening gelaten, bedroeg :

1886.

Hollandsche IJzeren Spoorwegmaatschappij . . . . 76,880

Nederlandsche Rijnspoorwegmaatschappij . . . . . 43,843

Société Grand Central Belge . . . . . . . . . 3,929

Nederlandsche Centraal-spoorwegmaatschappij . . . 7,498

Maatschappij tot exploitatie van Staatsspoorwegen. . 140,974

Noordbrabantsch-Duitsche spoorwegmaatschappij . . $\quad 6,637$

Spoorwegmaatschappij Gent-Terneuzen . . . . . 2,423

Spoorwegmaatschappij Mechelen-Terneuzen . . . . 1,110

Links-Rheinische spoorweg. . . . . . . . . . 154

Haarlem-Zandvoort spoorwegmaatschappij . . . . 4,855

Luik-Maastrichtsche spoorwegmaatschappij . . . . 913 
Bijzondere telegraaf-ondernemingen :

1886

1,729

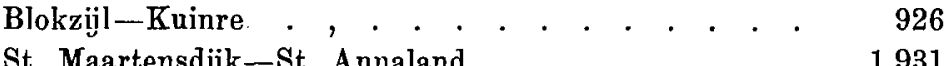

St. Maartensdijk-St. Annaland . . . . . . . . 1,931

Weesp-Muiden . . . . . . . . . . . . . 3,273

Middelburg-Domburg . . . . . . . . . 2,081

Vianen-Vreeswijk . . . . . . . . . . . . . 773

Arnhem-Elst . . . . . . . . . . . . . . 1,764

Heusden-Druren . . . . . . . . . . . . . 827

Heusden-Haarsteeg . . . . . . . . . . . . 571

Heusden-Wijk . . . . . . . . . . . . . . 1,030

Mijdrecht-Uithoorn . . . . . . . . . . . 1,908

Kortgene-Kolijnsplaat . . . . . . . . . . . 1,403

Waalwijk-Vrijhoevenkappel . . . . . . . . . 904

Schoonhoven-Ammerstol . . . . . . . . . . 3,137

De Minister heeft in zịnn Verslag geen melding gemaakt van de invoering van het nieuwe Wetboek van Strafrecht, waardoor de Wet op de telegrafie van 7 Maart 1852 (Staatsblad no 48) is gewijzigd en van de Wet van 15 April 1886 (Staatsblad no 65) waarbij maatregelen zijn vastgesteld ter bescherming van onderzeesche telegraafkabels.

De Regeering beschouwt de telephoon als te behooren tot den telegraaf; met regt mogt men dus verwachten, dat het Verslag ons bekend zou maken met den toestand der telephonen in het algemeen en van die in Nederland in het bijzonder; dit is evenwel het geval niet. Voor zoover wij uit Bijlage B van het Verslag op kunnen maken, hebben de telephoonkantoren, die met behulp van het Rijk zijn opgerigt en aan den Rijkstelegraaf aansluiten, in 1886 opgebragt $f 10,356$ tegen $f 8,036$ in 1885 . Deze bron van inkomst is van belang, omdat daartegen alleen de kosten van onderhoud staan. De kosten van aanleg zijn gering, omdat de gemeente die betalen moet, zoodra de afstand der gemeente tot de rijkstelegraaflijn meer dan 5 kilometer bedraagt; de gemeente moet zelf zorgen voor personeel en kantoor. De inkomsten van den Rijkstelegraaf zouden verbeteren, indien geleidelijk kon worden overgegaan, de kleinere telegraafkantoren te veranderen in telephoonkantoren. Een wetsontwerp tot Regeling der gemeenschap door electrische telephonen werd door de Regeering bij de Staten-Generaal ingediend, maar is niet in openbare beraadslaging geweest toen de Staten-Generaal in den zomer van 1887 ontbonden werden 
ten gevolge der grondwetsherziening, waardoor het wetsontwerp verviel.

Bij K. B. van 15 September 1886 (St. no 164) werden nieuwe voorwaarden vastgesteld, waarop met medewerking der gemeenten, rijkstelegraaf kantoren en rijkstelephoonkantoren in kleine plaatsen kunnen worden opgericht en in stand gehouden. Do vorige besluiten betreffende deze zaak waren niet zeer duidelijk en hebben herhaaldelijk tot klachten anleiding gegeven (zio bl. 1093 van den vorigen jaargang van dit Tijdschrift). Ook tegen het besluit van 15 September 1886 werden door den gemeenteraad van Haarlemmermeer den 28 October 1886 bijj de Tweede Kamer der Staten-Generaal bezwaren ingebragt. Dit adres is door de Kamer met verzoek om inlichtingen gezonden naar den Minister van Waterstaat, Handel en Nijverheid, en de ontvangen inlichtingen zijn gesteld in handen eener Commissie, die een Verslag uitbracht. De conclusie van dat Verslag was, den Minister dank te zeggen voor de gegeven inlichtingen en te verklaren, dat de in alinea 3 van art. 3 van genoemd besluit vervatte voorwaarde betrekkelijk vergoedingen, gevorderd tot $1 \mathrm{Ja}-$ nuari 1887, daarin niet te recht is opgenomen.

De bewuste alinea bepaalt, dat aan de gemeenten, die tot aan 1 Januari 1887 de vergoeding, die van haar gevorderd werd, zullen betaald hebben, ook na dat tijdstip de kosten van instandhouding in rekening zullen worden gebracht tot het bedrag, als met haar oorspronkelijk was overeengekomen.

De gemeenteraad van Haarlemmermeer beweerde, dat die vergoeding ten onrechte van haar gevorderd werd, en had deze daarom niet betaald; dien ten gevolge zou Haarlemmermeer in ongunstiger positie komen en was deze bepaling eigenlijk een middel haar te dwingen zekere ten onrechte van baar gevorderde sommen te voldoen.

Door de ontbinding der Staten-Generaal is de conclusie der Commissie niet in stemming gekomen.

Bij K. B. van 29 Juni 1886 (St. no 114) werd vastgesteld een nieuw Reglement voor den dienst der Rijkstelegraaf, ten einde de voorschriften in overeenstemming te brengen met het in 1885 te Berlijn herzien Internationaal telegraafreglement. Met Juli 1886 is dientengevolge een nieuw telegram-tarief in werking getreden. Volgens het oude tarief betaalde men voor een telegram, af komstig vall en bestemd naar een telegraaf kantoor in Nederland, een vast bedrag, grondtaks, van 15 cent en daarenboven voor ieder woord één cent. Volgens het nieuwe tarief wordt betaald voor een 
telegram tusschen twee Nederlandsche kantoren in verschillende plaatsen voor 10 of minder woorden 25 cent; voor telegrammen, die meer dan 10 woorden bevatten moet voor elke twee woorden boven de 10 woorden daarenboven betaald worden 3 cent, met dien verstande, dat als het aantal woorden niet door twee deelbaar is, voor de toepassing van het tarief een der woorden voor twee zal berekend worden. Een vergelijking der kosten in guldens van een binnenlandsch telegram volgens het oude en het nieuwe tarief geeft aan :

Aantal WOORDEN.

$\begin{array}{lllllllllllll}5 & 10 & 15 & 20 & 25 & 30 & 35 & 40 & 45 & 50 & 100 & 500 & 1000\end{array}$ $\begin{array}{llllllllllllll}\text { Oud tarief } & 0.20 & 0.25 & 0.30 & 0.35 & 0.40 & 0.45 & 0.50 & 0.55 & 0.60 & 0.65 & 1.15 & 5.15 & 10.15\end{array}$ $\begin{array}{llllllllllllll}\text { Nieuw " } & 0.25 & 0.25 & 0.34 & 0.40 & 0.49 & 0.55 & 0.64 & 0.70 & 0.79 & 0.85 & 1.60 & 7.60 & 15.10\end{array}$

$\mathrm{Bij}$ het nieuwe Reglement zijn ingevoerd stad-telegrammen, waardoor voor ieder telegram tusschen een rijkstelegraafkantoor en een hulpkantoor in dezelfde gemeente wordt betaald voor de eerste tien woorden vijftien cent en één cent voor elk woord daarboven. Voor de overbrenging van een dringend telegram wordt in het binnenlandsch verkeer het dubbel van den gewonen tarjefsprijs geheven, en vroeger het drievoud.

Ten gevolge van het nieuwe Internationale telegramtarief is de prijs der buitenlandsche berichten zeer verminderd. Gemiddeld bedraagt die vermindering 13 cent per telegram van tien woorden.

Door eenige uitgevers en hoofdredacteuren van dagbladen, enz. werden bij de Tweede Kamer bezwaren tegen het telegraaftarief ingebracht. De adressanten beklaagden zich hoofdzakelijk over de verhooging van het telegraaftarief, dat volgens hen een nieuwen last legt op den handel, vooral door den verhoogden prijs voor korte telegrammen, en op de uitgevers van dagbladen, die een aantal berichten en verslagen uitvoerig geseind krijgen en bijna de helft meer dan vroeger moeten betalen voor lange telegrammen. In sommige andere landen is voor de pers een tarief ingevoerd, belangrijk lager dan het gewone. Deze adressen werden naar den Minister van Waterstaat, Handel en Nijverheid gezonden, die den $23 n$ September 1886 inlichtingen aan de Kamer toezond (zie Zitting 1886-1887-58), welke inlichtingen in handen eener Commissie werden gesteld.

Den 9n December 1886 bracht die Commissie, bestaande uit de heeren de Bruyn Kops, van Kerkwijk, A. van Dedem, Bahlmann en Gildemeester, verslag uit. In dit verslag wordt medegedeeld, dat het tarief is verhoogd ter vermindering van het tekort op den 
dienst van den Rijkstelegraaf, welk tekort over 1885 ongeveer $f 600,000$ bedroeg. In den regel gaat met vermindering van het tarief vermeerdering van het aantal berichten gepaard, maar de opbrengst neemt slechts weinig toe, terwijl de uitgaven aanmerkelijk stijgen. De belangrijkste tariefverlaging had plaats in 1868 toen het tarief van 50 op 30 cent is gebracht. Van 1852 tot 1868 was het tarief zoo hoog, dat de opbrengst van een telegram hooger was, dan de kosten; van daar dat de opbrengst gedurende die jaren de exploitatiekosten overtrof. De intrest der kapitalen, door de schatkist aan den Rijkstelegraaf besteed, buiten rekening latende, was de opbrengst gedurende die jaren te zamen f 510,000 hooger dan de exploitatiekosten. $\mathrm{Na}$ de verlaging van het tarief in 1868 was er in plaats van een overschot in dat jaar reeds een kort van $f 63,000$; dat jaarlijksch tekort steeg tot $f 359,000$ in 1879 en tot $f 573,000$ in 1885 . Van 1868 tot het einde van 1885 was het gezamenlijke tekort over dat tijdperk $f 6,229,000$. Per telegram waren vóór 1868 de opbrengst 53 cent en de kosten 46 cent en thans respectievelijk 29 en 48 cent. Het telegraaftarief is dus zoo laag, dat op ieder telegram verloren wordt; op veel plaatsen maakt een vermeerdering van het aantal berichten het noodig meer per. soneel en materieel te hebben; in zulke gevallen kan men aannemen, dat hoe meer telegrammen hoe grooter het verlies is. Dikwijls wordt beweerd, dat verlaging van het tarief bij clen telegraaf dezelfde gunstige financieele gevolgen zal hebben, als bị de posterijen. Men verliest dan uit het oog, dat bij de posterijen het binnen zekere grenzen geen bezwaar is of kosten veroorzaakt, als het aantal brieven grooter is, lan. vroeger. Het aantal brieven kan aanmerkelijk toenemen, zonder voor het vervoer of bestellen meer personeel te behoeven. Bij de telegraphie is zulks niet het geval; ieder telegram moet afzonderlijk behandeld worden, en twee telegrammen vorderen ongeveer tweemaal meer arbeid dan één; zoodra het verkeer slechts eenigszins toeneemt, kan men niet meer met dezelfile arbeidskrachten volstaan, is vermeerdering van personeel en materieel er het gevoly van, dus verhooging der exploitatiekosten. Karig te zijn op personeel is moeielijk, omdat de telegrammen niet gelijkmatig over den geheelen dag worden aangeboden, maar het drukst op enkele tijden van den dag, en soms zeer onverwacht. Iedèr telegrafist kan slechts een beperkt getal telegrammen per dag behandelen; is het tarief zoo hoog, dat de opbrengst dier telegrammen de kosten voor den telegrafist, het materieel, enz. dekt, dan kan de opbrengst van den Rijkstelegraaf de liun. ISr7. 
uitgaven bestrijden. Is daarentegen het tarief zoo laag, dat de opbrengst der telegrammen, die de telegrafist kan behandelen, kleiner is dan de uitgaven voor dien beambte, enz. dan is er een tekort. Dit tekort vermindert niet door vermeerdering van telegrammen, want bij vermeerdering van het verkeer moet ook het personeel worden uitgebreid. Het tegendeel, vergrooting van het tekort zal het gevolg zijn van vermeerdering van het verkeer; slechts op die enkele plaatsen, waar het verkeer nog kan toenemen zonder meer exploitatiekosten, zal vermeerdering van het verkeer voordeelig zijn. Vergelijkt men het oude met het nieuwe tarief, dan blijkt, dat de prijs der telegrammen van 2 tot 10 woorden (dat is gemiddeld 353 van de 1000 telegrammen) niet noemenswaardig gewijzigd is; voor telegrammen van 11 tot 15 woorden (322 van de 1000) is het nieuwe tarief hooger en varieert het verschil tuschen 8 en 4 cent; van 16 tot 20 woorden (167 van de 1000) tusschen 9 en 5 cent; van 21 tot 30 woorden (108 van 1000) van 19 tot 10 cent; van 31 tot 40 tot woorden (26 van de 1000) van 24 tot 15 cent; van 41 tot 50 woorden (10 van de 1000) van 29 tot 20 cent. Men ziet hieruit, dat bij telegrammen van 21 tot 30 woorden de prijs aanzienlijk gestegen is, hetwelk bij telegrammen van 31 tot 40 woorden nog meer bedraagt. Het tarief van 41 woorden en daarboven is vrij hoog in vergelijking van het oude tarief. De telegrammen met een groot aantal woorden zijn meestal voor de dagbladen bestemd; het gevolg van de invoering van het nieuwe tarief is, dat de dagbladen meer dan vroeger moeten betalen; de zittingverslagen van de Staten.Generaal worden in den regel gedeeltelijk naar de dagbladen getelegrafeerd, ten einde 's avonds in de courant te kunnen verschijnen. Deze telegrammen bevatten dikwijls van twee tot vier duizend woorden.

Een telegram van vier duizend woorden kostte onder het oude tarief ongeveer $f 40$ en kost onder het nieuwe $f$ 60. Daar het publiek er belang bij heeft, dat de dagbladen volledige verslagen geven, betalen in Zweden en Frankrijk de perstelegrammen een lager tarief.

De Commissie stelde aan de Tweede Kamer voor:

10. de Minister van Waterstaat, Handel en Nijverheid dank te zeggen voor de gegeven inlichtingen, en een afdruk te zenden van het verslag;

20. als haar meening uit te spreken, dat spoedige regeling hij de wet van bet binnonlandsch telegramtarief wenschelijk is. 
Deze conclusie werd in de zitting der Tweede Kamer van 25 Februari 1887 na eenige discussie zonder stemming aangenomen.

Het nieuwe tarief heeft slechts over een half jaar,gewerkt; wij willen geen gevolgen trekken uit de opgegeven cijters omtrent de werking van het nieuwe tarief. Cijfers over een kort tijdsbestek bewijzen niets; de toestand van handel en nijverheid beheerscht het verkeer der Rịkstelegraat, verschillende minder invloedhebbende zaken komen hierbij.

Aan het einde van ons opstel over 1,885 drukten wij den wensch uit, dat het Verslag over 1886 zou bewijzen, dat het ernst is met de samenvoeging der posterijen en der telegrafen; van dien ernst is ons weinig gebleken. Tot staving van ons gevoelen wijzen wij op enkele zaken; nog steeds worden examens afgenomen voor ambtenaren, die te gelijker tijd surnumerair der posterijen en van den Rijkstelegraaf zijn; de telegrammen moeten met telegramzegels gefrankeerd worden, maar mogen zulks niet gedaan worden met postzegels, hoewel zelfs voor het sparen in de postspaarbanken postzegels worden gebezigd, enz. Een goede vereeniging der boide administratien is onmogelijk zonder geschikt personeel, en om dit te verkrijgen moeten voortaan geen ambtenaren voor één tak van dienst aangesteld worden, maar ambtenaren, die tot de beide administratien, die van den Rijkstelegraaf en van de posterijen, tegelijk behooren, slechts één corps vormen on opgeleid worden, om bij beide administratien dienst te doen.

J. J. VAN KERKWIJK. 